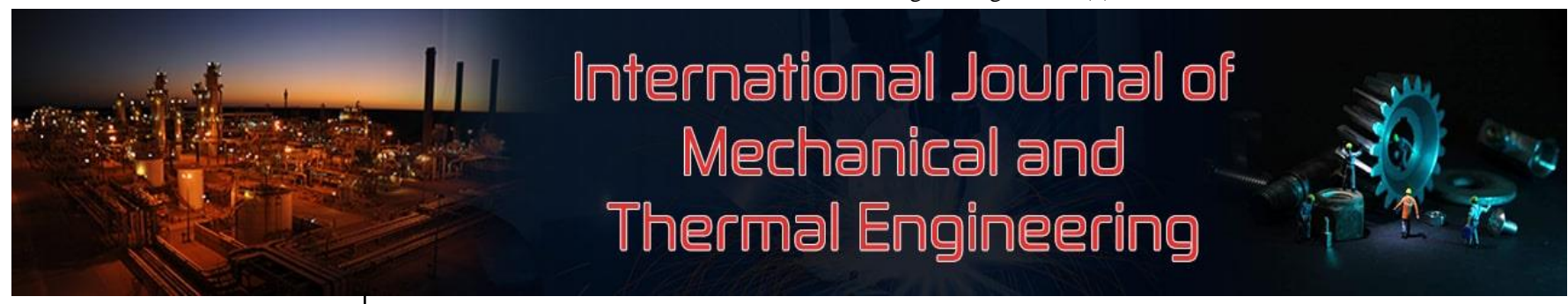

E-ISSN: 2707-8051

P-ISSN: 2707-8043

IJMTE 2020; 1(1): 37-42

Received: 20-11-2019

Accepted: 20-12-2019

Umirova Nilufar Ravilevna Tashkent State Technical University named after Islam Karimov, Uzbekistan

Rahmatillayev SHahzod

Fahriddinovich

Tashkent State Technical

University named after Islam

Karimov, Uzbekistan

Gafurov Doniyor

Sunatillayevich

Tashkent State Technical

University named after Islam

Karimov, Uzbekistan
Corresponding Author:

Gafurov Doniyor

Sunatillayevich

Tashkent State Technical

University named after Islam

Karimov, Uzbekistan

\section{Use of glauconite as a non-reagent sorbent for the softening of drinking and boiler waters, industrial waste water}

\section{Umirova Nilufar Ravilevna, Rahmatillayev SHahzod Fahriddinovich and Gafurov Doniyor Sunatillayevich}

\begin{abstract}
The article discusses the sorption of purification of water bodies from impurities using natural inorganic sorbents. The availability and low cost of minerals are an important economic advantage of their use for the purification of all types of water. The article describes a method of using an effective sorbent with high ion-exchange and sorption properties for purification of light oil products, for the purification of drinking or industrial water with a high content of heave technogenic metal ions and organic substances. Based on the data obtained, conclusions are drawn about the possibility of using the studied natural mineral sorbents for the extraction of impurities from waste and natural waters.
\end{abstract}

Keywords: glauconite, alum silicate mineral, sorbent, cation exchange, adsorption, water treatment, industrial wastewater, water hardness, technogenic impurities.

\section{Introduction}

In the modern world power supply questions in heat power branch have got a special urgency that is caused by reduction of water resources and an aggravation of ecological loads in environment. Now in the world more than $2000000 \mathrm{~m}^{3}$ a day desalted waters is made for the account nonconventional мембранных the technologies, allowing to raise to $30-40 \%$ technological efficiency of the steam-power equipment of thermal power plants (TPP). Therefore, carrying out of a complex of actions for the decision of problems energy saving and developments of use nonconventional, безреагентной technologies of water treating are actual. At the same time today, the problem of supply of the population qualitative potable water is in ecological practice of one of the sharpest. The reason of it is the overestimated general rigidity of potable water that can lead to heavy consequences. There is a direct communication between urolithic illness and superfluous rigidity of potable water ${ }^{[1-2]}$.

For today priority research works on working out of technology of improvement of quality of water on water preparatory installation in the conditions of Uzbekistan are carried out, including: perfection of methods of optimization of technological processes of water preparation; installation creation reversible an electrodialysis for restoration of water from drains clarifier for the purpose of returning in a tower for slag cooling; working out of installation for regeneration cyanides allowing to improve ecological conditions in many regions of the world; working out of installations of sewage treatment containing heavy metals; creation of special installations for residue a brine with recycling of the concentrate, containing mainly salts etc.

In Uzbekistan deterioration of superficial waters because of anthropogenesis pollution is observed. The water problem of region consists that resources of superficial waters practically are completely settled. Underground waters have considerable rigidity and a high mineralization in this connection they are not suitable for use as initial water in work cycles of the industrial enterprises without preliminary desalination. Besides, underground waters have the raised concentration of harmful elements, inadmissible to application under standard requirements for hot water supply (HWS) therefore by water preparation there is a necessity of their removal. The condition of the majority group water conduit morally and physically obsolete because of corrosion damages of pipelines and overgrowth is shown that, that leads to their repeated pollution, high cost of water that is economically unprofitable for objects of industrial and municipal power. Industry development, increase in number of motor transport, water use for needs of agriculture lead to the raised pollution of hydrosphere Work TPPS is connected with consumption of water from natural sources and formation of 
sewage with the raised maintenance of mineral components. Dump mineralized and organ-containing sewage in water sources leads to pollution of reservoirs, to deterioration of working conditions of other enterprises consuming water from this source, and also to increase of expenses for water preparation.

Variety of methods and technologies is developed for clearing of industrial sewage, such as flotation, a hyperfiltration, return osmose and others, allowing to reduce anthropogenesis loading on water objects. The final stage in technological processes, as a rule, is additional cleaning of drains with application sorption materials. Therefore, the problem of complex sewage treatment from these elements and organic connections is actual and working out of new sorbents has the big scientific and practical value. Sorption water treating methods are the most perspective and resource saving for water supply and water removal systems. Used sorbents should be simple in operation and possess high technical characteristics.

Quality of sewage from chemical clearings depends on type of the established equipment and an applied method of clearing and is accepted according to the chemical control. In the absence of data of the chemical control the structure of waste waters after their neutralization is applied according to technical and economic indicators (TEI) ${ }^{[2]}$ and tab. 1

Table 1: Approximate structure of impurity in sewage from chemical clearings of the equipment on TPPS, $\mathrm{mg} / \mathrm{dm}^{3}$

\begin{tabular}{|c|c|c|c|c|c|c|c|c|}
\hline \multirow[b]{2}{*}{ № } & \multirow[b]{2}{*}{ Indicator } & \multicolumn{7}{|c|}{ Methods of chemical clearings } \\
\hline & & Soljano-acid & Integrated & $\begin{array}{c}\text { Monoammonium } \\
\text { citrate }\end{array}$ & $\begin{array}{c}\text { Phthalic } \\
\text { acid }\end{array}$ & $\begin{array}{l}\text { Low molecular } \\
\text { acid concentrate }\end{array}$ & $\begin{array}{c}\text { Dicarboxylic } \\
\text { acids }\end{array}$ & $\begin{array}{c}\text { Hydrazine } \\
\text { acid }\end{array}$ \\
\hline 1 & Chlorides & 4500 & - & - & - & - & - & - \\
\hline 2 & Sulphates & 50 & 400 & 400 & 40 & 40 & 40 & 3000 \\
\hline 3 & Iron the general & 5 & 15 & 15 & 10 & 10 & 10 & 5 \\
\hline 4 & $\begin{array}{c}\text { Inhibitors } \\
\text { OP-7, OP-10 }\end{array}$ & 70 & 70 & 70 & 70 & 70 & 70 & - \\
\hline 5 & $\begin{array}{c}\text { Inhibitors } \\
\text { PB-5, V-1, V-2 }\end{array}$ & 30 & - & - & - & - & - & - \\
\hline 6 & Kaptaks & - & 15 & 15 & 15 & 15 & 15 & - \\
\hline 7 & Formaldehyde & 200 & - & - & - & - & - & - \\
\hline 8 & Ammonium connections & 500 & 500 & 500 & 280 & 500 & 280 & 280 \\
\hline 9 & Nitrites & - & 250 & 250 & - & 250 & - & - \\
\hline 10 & The dry rest & 10000 & 6000 & 6000 & 6000 & 6000 & 6000 & 6000 \\
\hline & $\begin{array}{l}\text { The maintenance of } \\
\text { organic substances: }\end{array}$ & & & & & & & \\
\hline 11 & $\begin{array}{l}\text { Chemical indicator of } \\
\text { oxygen, } \mathrm{mg} \mathrm{O}_{2} / \mathrm{kg}\end{array}$ & 350 & 1900 & 1700 & 3400 & 3000 & 2800 & - \\
\hline 12 & $\begin{array}{c}\text { Biochemical indicator of } \\
\text { oxygen, } \mathrm{mg} \mathrm{O}_{2} / \mathrm{kg}\end{array}$ & 180 & 650 & 1300 & 2400 & 2200 & 2200 & - \\
\hline
\end{tabular}

In table 2 the structure and concentration of pollution in sewage of Mubarek TPPS are resulted

Table 2: Composition and concentration of pollutants in the wastewater of the Mubarek TPP for the I-quarter of 2019

\begin{tabular}{|c|c|c|c|c|c|c|}
\hline Indicator & $\begin{array}{c}\text { Unit of } \\
\text { measure }\end{array}$ & Norm & January & February & March & Average \\
\hline $\mathrm{Fe}$ & $\mathrm{mg} / \mathrm{l}$ & 0,5 & 0,073 & 0,35 & 0,48 & 0,301 \\
\hline $\mathrm{Cu}$ & $\mathrm{mg} / \mathrm{l}$ & 1,0 & 0,031 & 0,43 & 0,21 & 0,22 \\
\hline $\mathrm{Cl}$ & $\mathrm{mg} / \mathrm{l}$ & 350 & 44 & 156 & 120 & 116 \\
\hline $\begin{array}{c}\text { The weighed } \\
\text { substances }\end{array}$ & $\mathrm{mg} / \mathrm{l}$ & 30 & 0,17 & 0,24 & 0,56 & 0,32 \\
\hline Mineralization & $\mathrm{mg} / \mathrm{l}$ & 1000 & 365 & 720 & 424 & 500 \\
\hline $\mathrm{NO}_{2}$ & $\mathrm{mg} / \mathrm{l}$ & 45 & 0,068 & 1,02 & 0,44 & 0,509 \\
\hline $\mathrm{NH}_{3}$ & $\mathrm{mg} / \mathrm{l}$ & 2,0 & 0,84 & 0,64 & 0,04 & 0,506 \\
\hline $\mathrm{SO}_{4}$ & $\mathrm{mg} / \mathrm{l}$ & 500 & 7,4 & 10,3 & 12,4 & 10,0 \\
\hline Mineral oil & $\mathrm{mg} / \mathrm{l}$ & 0,3 & 0,118 & 0,166 & 0,11 & 0,13 \\
\hline
\end{tabular}

With a view of reduction of dumps of sewage and accordingly a fence of fresh water it is recommended at stations below-mentioned actions:

- Reduction of a fence of fresh water for feed of turnaround system of cooling at the expense of use for this purpose weakly mineralized sewage from other systems TPP after their preliminary clearing. Drains concern such waters from water washing of the coppers, loosening and flushing waters of filters water preparatory installation, blowing-off waters of coppers, a condensate returned with fuel oil, water after cooling of bearings of rotating mechanisms and other Petro containing drains after their clearing of mineral oil rain and thawed snow from territory TPPS;

- Use for ashes and slag washout in system hydro ash catcher (SAC) of sewage from other systems TPP in exchange fresh water. For these purposes it is expedient to use salt drains water preparatory installation, blowing-off water of turnaround system of cooling, water after chemical clearings of the equipment, hydro cleaning of premises, etc.

- The reuse organization on the water-preparatory device (WPD) sewage, both own, and other technological systems, clarifiers, loosening and process waters of filters it is expedient to use blowing-off waters as initial water, and the fulfilled reclaiming solutions to use for repeated regeneration. As initial water on food WPD is admissible to use weakly mineralized drains of other technological systems after their preliminary clearing if that it is necessary, etc.

For sewage treatment the big interest is represented by natural sorbents which concerns glauconite. Essential advantages of this mineral are: the wide circulation, cheapness, availability, granular structure, thermal stability, good ion exchange and filtration properties, and also possibility by chemical and structural modifying directed to change technological indicators of a mineral ${ }^{[3]}$.

Glauconite - natural alum silicates with the general formula $\left(\mathrm{K}, \mathrm{H}_{2} \mathrm{O}\right)\left(\mathrm{Fe}^{3+}, \mathrm{Al}, \mathrm{Fe}^{2+}, \mathrm{Mg}\right)_{2}\left[\mathrm{Si}_{3} \mathrm{AlO}_{10}\right](\mathrm{OH})_{2} * \mathrm{n} \mathrm{H}_{2} \mathrm{O}^{[4]}$. Glaukos ( $\gamma \lambda \alpha v \kappa o ́ \varsigma)$ - on it is Greek "aeruginosa", a mineral of group of hydromicas of a subclass of layered silicates 
widespread in sedimentary breeds, autogenic monoprismatic a mineral from group alum silicates, possessing high absorptions and cations-exchange properties. Rather widespread in some deposits of a sea origin. Maintenances of the main components in typical glauconite fluctuate in following limits (in\%): Potassium oxide $\left(\mathrm{K}_{2} \mathrm{O}\right)-4,0 \div 9,5$; oxide sodium $\left(\mathrm{Na}_{2} \mathrm{O}\right)-0 \div 3,5$; oxide aluminum $\left(\mathrm{AL}_{2} \mathrm{O}_{3}\right)$ $5,5 \div 22,6$; Iron trioxide $\left(\mathrm{Fe}_{2} \mathrm{O}_{3}\right)-6,1 \div 27,9$; Iron oxide $(\mathrm{FeO})-0,8 \div 8,6$; oxide magnesium $(\mathrm{MgO})-2,4 \div 4,5$; silicon dioxide $\left(\mathrm{SiO}_{2}\right)-47,6 \div 52,9$; water $\left(\mathrm{H}_{2} \mathrm{O}\right)-4,9 \div$ 13,5 . In the form of impurity are present: $\mathrm{CaO}$ to $1 \%$ (higher maintenances are usually connected with $\mathrm{CO}_{2}$ in the form of a carbonate), sometimes $\mathrm{P}_{2} \mathrm{O}_{5}, \mathrm{~B}_{2} \mathrm{O}_{3}$, etc. ${ }^{[5]}$.

Glauconite possesses enough high ability to cationic to an exchange, then and it is caused its uses for the industrial purposes. Increase of productivity of soil, land improvement, manufacture of organon-mineral fertilizers, improvement and restoration of soils, sewage treatment, catching of gases, elimination of smells, neutralization of floods of mineral oil, sorption heavy metals, radionuclides and toxicants can be used in such processes as water purifications drinking and a process water, sorption and dehydration of mineral oil, clearing and regeneration of power oils, preparation of water for steam and gas generators and boilers, as the fodder additive in animal industries, poultry farming, fish culture. Such application is based on its ability to reactions cations an exchange. For these purposes glauconites concentrates are preliminary processed by a table salt solution therefore sodium ions are absorbed by a concentrate. At filtering through such concentrate of hard water there is an exchange cation: alkaline earth cation waters are absorbed, and in a solution pass cation sodium, then and decrease in rigidity of water is caused.

High efficiency glauconite is established at clarification of water from salts of heavy metals, of some organic and inorganic structures, radionuclides ${ }^{[5]}$. Activated glauconite at a filtration through it of the polluted waters practically completely detains iron and ammonia structure, almost 10 times lowers contained in water of mineral oil, at 20-25 time lowers contents of radioactive isotopes of caesium-137 and strontium-90. High adsorptions and cation exchange properties glauconite can be used not only in quality adsorption heavy metals, oil sludge, polluting water objects and soil, and also for liquidation of the pollution which are in deposits of treatment facilities and industrial drains, in ground and water objects, by means of the vulgar entering and creation of geochemical barriers. Glauconite it is applied at rehabilitation of the territories amazed radionuclides or having high technogenic loading as a result of activity of the industrial enterprises. It is effectively used in rural, a national economy and the industry for neutralization of floods of mineral oil, clearing and restoration of soils, catching of gases, sewage treatment, sorption heavy metals, toxicants, radionuclides. It is an irreplaceable resource for reclamation dumps municipal solid waste (MSW) as it catches landfill gases and does not give them to more environment.

It is revealed ${ }^{[6]}$, that clay breeds possess a high measure chemical inertia or protective properties of the equilibrium condition established in them that proves to be true presence in them of some buffer action factors. Collodion-disperse minerals concern major of them, sparingly soluble salts of the basic or acid character, structure exchange cations and anions, a parity in ashes-gel to a phase acidosis and basoids, the maintenance humus substances etc. Besides, is important for noticing, that clay and clay breeds steadily exist in rather narrow area $\mathrm{pH}$, from 5 to 5,8 - two-layer fluosilicates kaolinite, allofan, galluasit and from 6,5 to 8 - biotite, muscovite, glauconite, montmorillonite, illit, chlorite, etc. Therefore, at entering into Wednesday (ground, waters) alum silicate, capable to displace reaction of environment for limits of area of steady existence of clay minerals of breed, it will be subject to intensive hydrolysis. However, to the beginning of realization of such destructive process counteracts buffer action factors. But, as glauconite that is difficult mineral system, according to principle Le-Shatele, it renders braking counteraction adverse for its steady condition to change of reaction of environment. Therefore, factors of buffer action of clay breeds are as though primary means of maintenance of processes of self-organizing at protection of the generated structural structure of clay breed or a primary stage specified above braking counteraction. If aggressive influence of chemical reagents completely overcomes action of factors of buffer action of breed (i.e. suppresses them) counteraction to these processes is carried out at the expense of buffer action of crystal lattices of the basic mineral, in our case GLAUCONITE. In particular, from its crystal lattices is extracted those oxides which are capable to render neutralized counteraction to ions of the chemical reagent which has caused adverse changes $\mathrm{pH}$ of environment.

Sorption substances glauconite - the multiphasic process directly depending on porosity of a sorbent and backlashes between contacting particles. Glauconite it is characterized by an active absorbing surface and presence of functional groups (silanols, silicanes, etc.), capable to connect ions of the various nature ${ }^{[7]}$.

According to ${ }^{[8]}$, possibility sorption softening drinking and boiler water of installations of an average and a high pressure with concentrate use glauconite as a sorbent with its finishing to standard requirements, accordingly, 7 and $0,10 \mathrm{mmol}-\mathrm{ekv} / \mathrm{l}$ is considered. Maximum sorption it is reached in 20-40 minutes from the process beginning. Thus the general initial rigidity of potable water decreases on 35$40 \%$, and boiler water at two-cyclic clearing on magnesium on $96 \%$, on calcium almost on $100 \%$.

One of important and a challenge, at softening the natural waters arriving for household needs from artesian water fences and superficial sources, is, absence cheap under the cost price and accessible sorbents. To consider as base synthetic products, including various cations, for these purposes it is unpromising. The matter is that scale softening such waters demands huge weight cationic, considerably exceeding their existing manufacture. From here and inevitable deficiency. Besides, synthetic cations are insufficiently studied in relation to softening the waters comparable and even essentially exceeding concentration sulphate, nitrate and a hydro carbonate of ions in comparison with the maintenance cations rigidity.

It is known, that in a basis cation an exchange at softening waters lay following processes ${ }^{[9]}$ :

- sorption;

- regeneration;

- loosening.

As a whole, regeneration very dirty process ${ }^{[10]}$ generating great volume highly mineralized of drains, demanding, in 
turn expensive regeneration. And, since strongly acidic cations as sorbents meet rather widely it should be recycled their big enough weights, creating essential volumes of sewage. Hence, it is expedient to replace these sorbents also with others which can be utilized economically expediently, not resorting to regeneration. It is a serious ecological problem.

With specified questions deep softening the waters, being as it was already marked, are socially-environmental problems closely connected by one of the reasons of high expenses also at use of heat of boiler installations. It is a question, first of all, of the water directed on a food of coppers of a high pressure. Special demands are made to such water ${ }^{[11-17]}$ in general. For similar devices with natural cooling the feedwater should meet following standard requirements:

The general rigidity no more:

- For gas pipe and fire tube the coppers working on firm fuel, - 0,5 mmol-ekv/l;

- For gas pipe and fire tube the coppers working on gaseous or liquid fuel, - 0,03 mmol-ekv/l;

-For water trumpet coppers with working pressure $13<\mathrm{P}$ $<39 \mathrm{kgs} / \mathrm{sm}^{3}$ - 0,015 mmol-ekv/l.

Let's preliminary notice, that the scum represents averages and basic salts $\mathrm{Ca}$ (II) and $\mathrm{Mg}$ (II)- $\mathrm{CaCO}_{3}, \mathrm{Mg} \mathrm{CO}_{3}$ [9/12], $\left[\mathrm{Mg}_{4}\left(\mathrm{CO}_{3}\right)_{3}(\mathrm{OH})-9 \mathrm{H}_{2} \mathrm{O}{ }^{[18]}\right.$.

Naturally, formed components of a scum essentially differs on properties. So, for example, solubility $\mathrm{CaCO}_{3}$ decreases with temperature growth, and speed of adjournment of a carbonate of calcium, owing to a number of its features, should not exceed $0,25 \mathrm{~g} /(\mathrm{m} 2 * \mathrm{~h})$. It was one of the basic requirements to the water spent for feed of turnaround systems, connected with restrictions on its rigidity.

Existing numerous methods of water treating from cations rigidity [11-13], of course, differentiated by efficiency concerning scum components. Deep softening waters can be reached by means of two phasic osmose with the subsequent tap permeate on decarbonization and definitive demineralization in filters of the mixed action ${ }^{[18]}$. But such approach conducts to essential increase of the cost price of a heat supply of the population, expenses on which constantly grow, strengthening social and economic intensity. However, turnaround water goes not only in heat exchange turnaround systems. It is spent in technological and power processes. In this case its rigidity should be less, than in systems of turnaround water supply - the maintenance of salts no more than $10 \ldots 15 \mathrm{mg} / \mathrm{l}$, rigidity $<0,020 \mathrm{mmol}$ $\mathrm{ekv} / \mathrm{l}^{[19]}$ is more exact.

Expediently widely to use natural sorbents for the decision of problems softening waters as complex method of protection of environment by means of volume decrease high mineralized drains and improvement of health of the population, reduction of social and economic intensity. In this respect is available also defined, though and the extremely limited experience. One of natural sorbents glauconite, meeting in powerful superficial deposits, practically does not lose the properties at hour action with hydrochloric acid $(\mathrm{HCl})$. According to ${ }^{[20]}$, application clinoptilolite sorbents at water treating under the scheme: chlorination $\rightarrow$ ozonation $\rightarrow$ contact coagulation leads to essential decrease in its chromaticity and turbidity. In ${ }^{[20]}$, it is informed on 10-fold use bentonite for water treating from finely dispersed oil and mineral oil with stage-by-stage washing a sorbent ligroin and regeneration in special furnaces. It is used for this purpose natural sorbents in the USA ${ }^{[20]}$. In Japan on base alum silicates the sorbent for removal Cd (II) and $\mathrm{Cr}$ (II) of sewage is received. At the industrial enterprises of the USA, France, Japan the mix montmorillonite and poligorskite is with that end in view used.

Thus, search and research are necessary for the decision listed above problems of protection of a surrounding environment and population health physical and chemical and sorption characteristics of ecologically pure natural sorbent accessible on volume which extraction is possible in the open way. The similar sorbent should have deposits in various regions of the country, allow to lower to standard indicators rigidity of potable water on installations of various productivity and in volumes, sufficient for satisfaction of requirement of the population of the big and small cities. Use of such sorbent as follows from stated, should allow is essential to lower volumes high mineralized sewage or them completely to eliminate, reduce the price of logistics. The sorbent should work effectively in the presence of considerable concentration (1-10 mmol/l) anions $\mathrm{SO}_{4}{ }^{2}-\mathrm{NO}^{-3}, \mathrm{HCO}^{-3}, \mathrm{HSO}^{4}$ - commensurable or exceeding the maintenance cations rigidity (Ca (II), $\mathrm{Mg}$ (II)), present in artesian or superficial water. Thus, softening waters it should be possible over a wide range according to technological problems, and the fulfilled sorbent - to suppose economically and toxicologically expedient recycling.

In Republic Uzbekistan bowels the considerable quantity of various kinds of the minerals which use promotes development of economy of the state ${ }^{[21]}$ is concentrated. These minerals represent a raw-material base for production, best-selling in the internal and world markets. In the glauconite Uzbekistan it is developed in sandyargillaceous adjournment of the Gissar range, ZiaetdinZirabulak mountains, Kizilkum raisings, Sultaunizdag, and also in Northern Fergana and in Tashkent geological area, deposits glauconite sandstones - Kofrun, Chang, Aksu, Bolgali, Tagarasay and Mobika also are revealed. Qualities glauconite sandstones on displays Krantau have been studied. Besides deposits 17 perspective displays ${ }^{[22]}$ are revealed.

It is established, that glauconite sand from deposits Krantau contains basically glauconite, quartz, anorthite, feldspar, illite, muscovite and galite.

Presence in Uzbekistan a large Krantau deposit glauconite, does actual working out on its basis of sorbents, suitable to use as loading of filtering constructions for sewage treatment from technogenic impurity on industrial productions.

The chemical compound glauconite from deposits Krantau is characterized by following data $(\%){ }^{[22]}: \mathrm{SiO}_{2}-70,27$; $\mathrm{AL}_{2} \mathrm{O}_{3}$ - 9,95; $\mathrm{Fe}_{2} \mathrm{O}_{3}$ - 4,95; $\mathrm{K}_{2} \mathrm{O}-3,08 ; \mathrm{Na}_{2} \mathrm{O}-2,46 ; \mathrm{CaO}-$ 0,$80 ; \mathrm{MgO}-0,99 ; \mathrm{MnO}-0,05 ; \mathrm{TiO}_{2}-0,49 ; \mathrm{P}_{2} \mathrm{O}_{5}-0,10 ; \mathrm{SO}_{3}$ - 0,72. In mineral structure glauconite breeds of the Krantau deposit presence of 35 minerals is established.

The capacity cations a concentrate exchange glauconite changes from 390 to $550 \mathrm{mg}$-ekv, natural glauconite the Krantau (ore) - to 250 - $300 \mathrm{mg}$ - ekv on $1 \mathrm{~kg}$ of ore. The mineral possesses ability of selective absorption cationic and long-living radioisotopes. Limiting absorbing ability glauconite in relation to heavy metals looks belowmentioned image: on copper - 781,2; on nickel - 342,4; on zinc - 827,7; on gland - $1317,8 \mathrm{mg}$-ekv. on $1 \mathrm{~kg}$ of a mineral.

Ability glauconite to take heavy metals from solutions makes (in \% from the initial maintenance): $\mathrm{Pb}-99, \mathrm{Hg}-64$, 
Co - 97, Cu - 96, Mn - 95, Cr - 92, Ni - 90, Zn - 90, Fe - 99. Glauconite is a qualitative water softener, the good pigment of green color proof to atmospheric influences, and also adsorptions, on quality not conceding using now at processing of mineral oil and clearings of industrial sewage. Glauconite also is of interest at clearing of radioactive drains. Possessing high sorption in capacity to radioactive salts, glauconite the filter after processing easily conglomerates in vitreous weight in which radioactive salts pass in an insoluble condition that facilitates a burial place of the fulfilled filters. The additive glauconite in cement as filler promotes reception of the concrete interfering penetration both rigid, and soft radioactive radiation. Despite the specified merits glauconite, its practical use till now the insignificant. The developed requirements of the industry to glauconite to raw materials are absent now. Breeds with rather high maintenances glauconite (more than 25-30\%), apparently, can be used in a natural kind, and breed with the smaller maintenance glauconite demands enrichment.

It is necessary to notice, that works on application glauconite the Kofrun, Changi, Aksu and Mabik deposits in clearing processes, additional cleanings are more exact, some water, in Uzbekistan was not spent. Therefore, samples glauconite the Krantau deposit for clearing drinking water and sewage of Mubarek TPP have been investigated. Researches of structural-morphological features, physical and chemical are carried out, ion exchange characteristics glauconite the given deposit show possibility of its application in water preparation schemes. The basic physical and chemical indicators glauconite the Krantau deposit are resulted in table 3.

Table 3: The basic physical and chemical indicators glauconite

\begin{tabular}{|c|c|c|c|}
\hline \multirow{2}{*}{$\begin{array}{c}\text { Specific surface on BET method, } \\
\mathbf{m} 2 / \mathbf{g}\end{array}$} & \multicolumn{3}{|c|}{ Volume pores, $\mathbf{s m}^{\mathbf{3}} \mathbf{g}$} \\
\cline { 2 - 4 } & micro & $\mathbf{m e z o}$ & the total \\
\hline 20,56 & 0,0027 & 0,026 & 0,033 \\
\hline
\end{tabular}

Preliminary in water the maintenance of investigated ions has been defined. Concentration of the general iron it is defined by a photometric method on device FEK-2 with sulfosalt acid, cations calcium and magnesium complexometric titration Trillon B from indicators eriochrome black $\mathrm{T}$, sulphate-anions - turbidimetric a method, chlorides-ions - titration by nitrate silver in the presence of the catalyst chromic acid kalium. Qualification reactants clean for analysis are used. Initial water was passed through ion exchange a column filled with the investigated sorbent, water was filtered and in a filtrate are made definition cations $\mathrm{Ca}^{2}+\mathrm{Mg}^{2}{ }^{+}, \mathrm{Fe}^{2+}$ and $\mathrm{Fe}^{3+}$ and anions $\mathrm{Cl}^{-} \mathrm{SO}_{4}^{2}$.

Table 4: Results sorption ions glauconite according to the chemical analysis

\begin{tabular}{|c|c|c|}
\hline$№$ & Investigated ions & Mass fraction absorbed adsorbate, \% \\
\hline 1 & $\mathrm{Fe}^{2+}$ и Fe & 30,2 \\
\hline 2 & $\mathrm{Ca}^{2+}$ & 79,8 \\
\hline 3 & $\mathrm{Mg}^{2+}$ & 76,8 \\
\hline 4 & $\mathrm{Cl}^{-}$ & 70,9 \\
\hline 5 & $\mathrm{SO}_{4}^{2-}$ & 68,4 \\
\hline
\end{tabular}

According to the received data, glauconite the Krantau deposit it is effective sorb ions $\mathrm{Ca}^{2}+\mathrm{Mg}^{2+}, \mathrm{Cl}-\mathrm{SO}_{4}{ }^{2-}$ to a lesser degree cations gland and also, rigidity decrease, for the account sorb abilities of a mineral, has averaged $78 \%$.
Studying kinetics only ions $\mathrm{Fe}^{2+}$ has shown adsorptions, that absorption of these cations Krantau glauconite makes 65$70 \%$ and is reached for 30-45 minutes. Research of adsorption of ions $\mathrm{Fe}^{2}+$ was spent by a method of measurement of kinetic curves in stationary conditions. For this purpose, hitch adsorption by weight 2 grammes it was maintained in $250 \mathrm{ml}$ to the distilled water in a current 24 hours. After decanting adsorbent in a damp condition, it was filled in just done with solution $\mathrm{FeSO}_{4} * 7 \mathrm{H}_{2} \mathrm{O}$ with the maintenance cations $\mathrm{Fe}^{2}+21 \pm 1 \mathrm{mg} / \mathrm{l}$ (in the ratio $2 \mathrm{~g}$ a sorbent and $100 \mathrm{ml}$ of a solution). Sorption cations it was spent at continuous hashing by a mixer in a current of 45 minutes. Through each certain time were selected and tests X-ray fluorescence on a method calibration a curve was analyzed by way. On the basis of the received data calculation of equilibrium concentration of ions $\mathrm{Fe}^{2}+(\mathrm{Cp})$ and their adsorptions $(\mathrm{G})$ was carried out

In table 5 and on fig. 1 results sorption ions $\mathrm{Fe}^{2+}$ glauconite the Krantau deposit are presented.

Table 5: Results of adsorption glauconite ions $\mathrm{Fe}^{2+}$ in time

\begin{tabular}{|c|c|c|c|}
\hline № & t, minuts & $\mathbf{C p , ~} \mathbf{~ m g / l i t e r}$ & $\mathbf{G}^{*} \mathbf{1 0}^{\mathbf{9}}, \mathbf{~} \mathbf{~ g / \mathbf { s m } ^ { \mathbf { 2 } }}$ \\
\hline 1 & 0 & 0 & 0 \\
\hline 2 & 5 & 15,97 & 3,87 \\
\hline 3 & 15 & 13,1 & 4,12 \\
\hline 4 & 30 & 6,01 & 7,46 \\
\hline 5 & 40 & 5,81 & 7,66 \\
\hline 6 & 60 & 5,92 & 7,54 \\
\hline
\end{tabular}

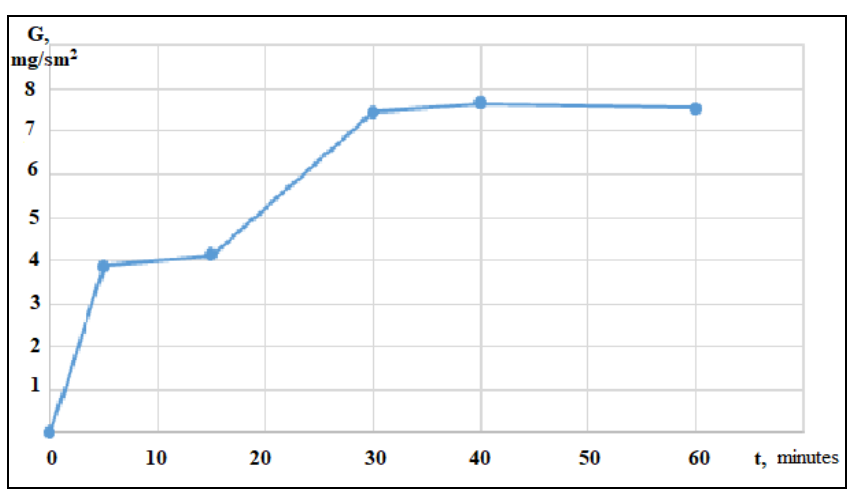

Fig 1: The dependence of the adsorption of $\mathrm{Fe}^{2+}$ ions by Krantau glauconite on time.

\section{Ariphmetic mean values from five measurements are used.}

The obtained experimental data indicate that sorption equilibrium is achieved in $30-40$ minutes. The concentration of sorbet $\mathrm{Fe}^{2+}$ glauconite cations under equilibrium is $15,97 \mathrm{mg} / \mathrm{l}$ or about 73 mass.\% of the initial value.

As shown by the analysis of samples of drinking water and industrial effluents from Mubarek TPP that passed through such an experimental installation, its properties after water treatment are significantly improved. Further development in this direction is the search for new variants of sorbents with high technological and sorption properties that can be used to treat highly concentrated industrial wastewater.

Analyzing the experimental data, we can draw the following conclusions

1) Glauconite of the Krantau deposit has a high sorption with respect to non $\mathrm{Ca}^{2+}, \mathrm{Mg}^{2+}, \mathrm{Cl}^{-}, \mathrm{SO}_{4}{ }^{2-}$, which makes it possible to use it as a natural water softener in water treatment processes; 
2) The adsorption of $\mathrm{Fe}^{2+}$ ions by glauconite is $70-73 \%$, while the adsorption of $\mathrm{Fe}^{2+}$ and $\mathrm{Fe}^{3+}$ ions together from tap water is only $30,2 \%$, which is probably due, under certain conditions, to the release of $\mathrm{Fe}^{3+}$ ions from the ionize crystal lattice.

3) The conducted studies are relevant for the use of glauconite as sorbents in water treatment processes.

4) Sorbent allows you to purify water from a large number of inorganic and organic and compounds at minimal cost.

\section{References}

1. Djunusova LR. Ochistka stochnyx vod system GVS s membrannym blokom $\mathrm{v}$ solnechno-vodorodnoy opresnitelnoyustanovke dlya usloviy Priaralya //EJ «APRIORI. Seriya. Estestvenniye I texnicheskiye nauki»-Krasnodar. 2015; 3:S20-40

2. Systemy ochistki vody. URL: http;//systemyochistkivody.ru//

3. Rukovodstvo po rpoektirovaniyu obrabotki I ochistki proizvodstvennyx stochnyx vod teplovyx elektrostansiy. M-: Informenergo, 1976.

4. Betextin A.G. Kurs mineralogii. M, 1956, S451

5. Vigdorovich VI, Tsygankova DV, Nikolenko DV. i dr. Adsorbsionnaya sposobnost glaukonita Bondarskogo rayona Tambjvskoy oblasti. // Sorbsionnii i xromotagraficheskiye protsessy. -Voronej: Voronejskiy gosudarstvenniy universitet.. T.10. Vypusk.S, 2010, 121-126.

6. Kanselson Yu. Ya Glaukonit soderjajiye mikrokonkresii kak poglotiteli radionuklidov / Yu.Ya. Kanselson, O.M.Aleksanyan, A.M.Voloshina // Mineralogiya i geoximiya glaukonita. - Novosibirsk, 1981, S80-89.

7. Andronov SA. Glaukonit - mineral budushego/ S.A.Andronov, V.I. Bykov // Materialy IMejdunarodnoy conferensii «Znacheniye promyshlennyx mineralov $\mathrm{v}$ mirovoy ekonomike: mestorojdeniya, texnologiya, ekonomicheskaya otsenka». - M.: GEOS, 2006, S79-83.

8. Levchenko ML. Glaukonity Sentralnogo mestorojdeniya: tipomorfniye osobennosti, rezultaty mineralogo-texnologicheskix issledovaniy / M.L. Levchenko, N.G. Patyk-Kara, E.A.Andrianova. -M.: MISiS: Sbornik tezisov VI kongressa obogatiteley stran SNG. 2007; 2:77-79.

9. Kochanovskiy AM, Klimenko NA, Levchenko TM, Morutovskiy RM, Roda IT. Ochistka i ispolzovaniye stochnyx vod v promyshlennom vodosnabjenii. M.: Ximiya, 1983, S228.

10. Muxlenov IP, Tambovseva VD, Gorshteyn AE, Osnovy Ximicheskoy texnologii M. Vyssh. Shk, 1975, S.344.

11. Lukinyx NA, Lipman BL, Krishtul VP. Metody doochistki stochnyx vod M. Stroyizdat, 1974, S96.

12. Roddante KF. Kotelniye ustanovki M. Nedra, 1977, S432.

13. Sbornik pravil i. rukovodyashix materialov po kotlonadzoru (Trebovaniya $\mathrm{k}$ pitatelnoy vode). M, 1977, 480.

14. Panin VI. Spravochnik po teploenergetike v selskom xozaystve. M.: Rosselxozizdat, 1979, 333.

15. kochanovskiy AM, Klimemko NA, Levchenko TM, Morutovskiy RM, Roda IT. Ochistka i ispolzovaniye stochnyx vod $\mathrm{v}$ promishlennom vodosnabjenii. M.:
Chimiya, 1983, 228.

16. Deev LV, Balaxnichev NA. Kotelniye ustanovki i ix obslujivaniye. M.: Visshaya shkola, 1950, 239.

17. Molchanov IA. Ekspluatatsiya parovix kotlov i parotruboprovodov. Kiev: Texshka, 1969, 668.

18. Kumok VN, Kuleshova OM, Karabin LA. Proizvedeniye rastvorimosti. Novosibirsk: Nauka, 1983, 229.

19. Nekrasov BV. Osnovi obshey ximii: 2 t. M: Chimiya, 1967; T2:408.

20. Tarasevich Yu I, Ovcharenko FD. Adsorbtsiya na glinistix mineralax. Kiev: Naukova dumka, 1975, 532.

21. http://www.mineral.ru/News/1669.html

22. http://cyberleninka.ru/article/n/metody-obogasheniyaglaukonitovyh-peschanikov-krantauskogomestorojdeniya-karakalpakstana-po-suhomusposobu/viewer

23. http://www.glaukos/ru

24. http://www.catalogmineralov.ru/mineral/419.html

25. http://professional.ru/Soobschestva/ecopuls/glaukonit/

26. wiki.web.ru/wiki/glakonit 